Vol. XIV, No. 2

\title{
Wintering Pigeon Hawks
}

\section{By J. F. ROY, Saskatoon}

How frequently does the pigeon hawk winter in Saskatchewan? During the past eight winters this bird has been reported from four widely separated areas. On December 31, 1948, Maurice Street of Nipawin recorded the first wintering pigeon hawk in the annual Christmas Bird Count (Blue Jay, Vol VII, No. 1, page 12). Three years later, December 26, 1951, Yorkton observers added a second wintering bird to the provincial records (Blue Jay, Vol. X, No. 1, page 15). During the winter of 1954-55, the Regina Natural History Society studied a bird which frequented the grounds of the Legislative Buildings (Blue Jay, Vol. XIII, No. 2, page 39). Again, on December 26,1955 , Regina members were able to add a pigeon hawk to the Christmas Bird List. (Blue Jay, Vol. XIV, No. 1, page 6).

Now it is Saskatoon's turn. The writer and Bernie Gollop have each seen the pigeon hawk on two occasions this winter. The first bird was noted flying over the Saskatchewan River, February 15, 1956. Three days later one pigeon hawk was noted two miles south of the city and another was seen within city-limits. The last observation was made on February 19 when Bernie Gollop noted the hawk along the highway five miles east of Sutherland. It does not seem likely that all four records were of the same bird.

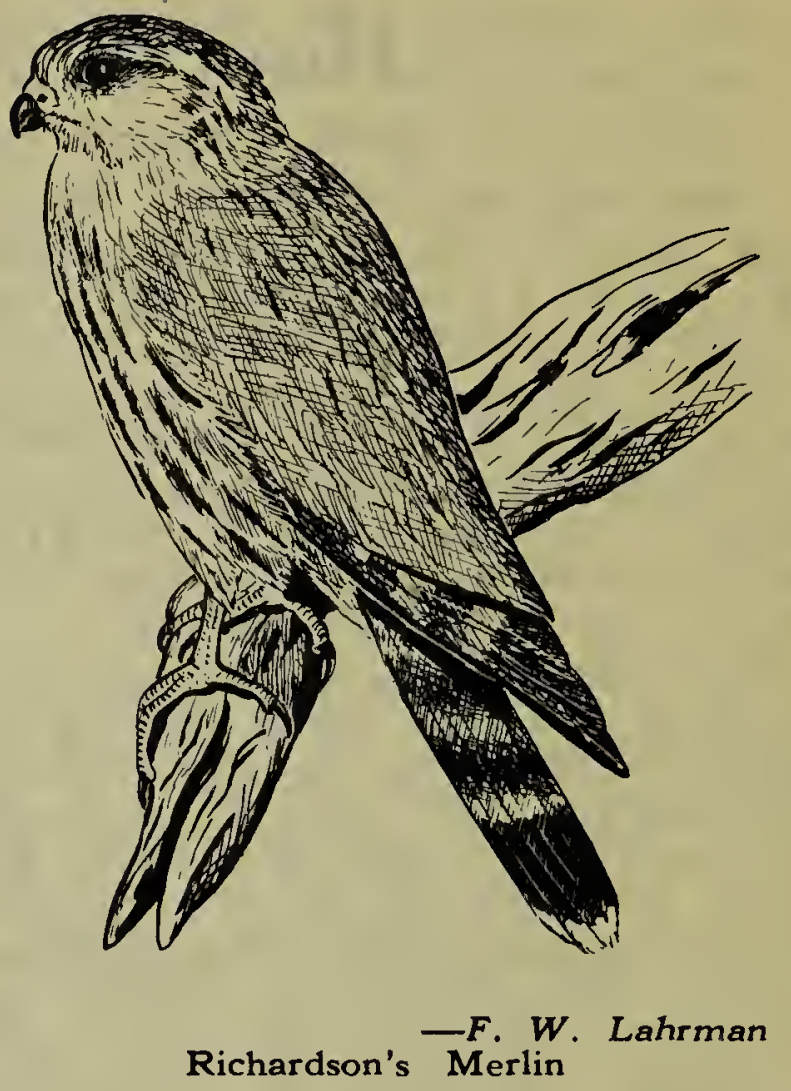

The evidence is that the pigeon hawk is a sporadic winter resident in Saskatchewan. Since the inauguration of the Christmas Bird counts many new facts about winter distribution have come to light. It is likely that many more of our hawks and owls remain for the winter than was once suspected. Short-eared owls and prairie falcons, for instance, turn up every year in the bird counts. Any observations of wintering pigeon hawks and prairie falcons would be most welcome.

EDITOR'S NOTE: The Saskatchewan Museum of Natural History has a recent specimen record of the Pigeon Hawk (6046 - study skin). This specimen was received December 17, 1955, from Frank Brazier who picked it up dead in the Legislative Grounds, Regina. It was identified as a female Richardson's Merlin ( $F$ alco columbarius richardsoni).

\section{Try "Drawing" Bird Song}

By MARIAN NIXON, Wauchope, Sask.

When trying to identify a new bird, from illustrations in a book or its descriptive test, one often thinks, "If they only gave its song, how much simpler identification would be!" But to date, I have found only one book, Schuyler Matthews' Wild Birds and their Music that helps one in this way.

However, I worked out my personal method of recording birdsong, which acts as a sort of shorthand of their music which I can later interpret with the ear of memory.

You will have noticed that it is hard for some children, and even older persons, to remember just how a certain bird tune goes once they no longer, hear it. Again, when another spring comes, a song is remembered as familiar yet one cannot remember which bird it was that used those notes.

When a person deliberately tries to make a memory last, one notices more carefully the various details. 
One can improve the hearing-memory just as one can improve the visual memory, and often one sense is used to help and impress the other. So, by "drawing a song" sight aids hearing, just as you often touch an object to help you see it in your memory.

This is what I mean by "drawing a song." One can draw a line, or graph, of the rises and falls in the bird's melody. By the heaviness or thinness of line, one can also show whether the notes are loud or soft, and one can even show if they come fast or slowly.

For instance, the Redwing blackbird's song is "conk-er-eee." When drawing it, the first syllable is the starting point in the line, the "er" is very slightly lower, and the "eee" rises in a sharp, curving line.

The Brewers' blackbird son is not so loud, so the line will be lighter and the cadences inverted, the line first holding a rising curve and then falling away again.

Try drawing what a crow says and you will find it a series of short, heavy lines, ever so lightly bulged in the centre. Then try marbled godwit's "Korreck, korreck" and see how different it looks from a crow's.

In contrast to these rather staccato calls, draw the haunting, long swelling then fading curve of the Upland plover's whistle.

Do you remember in Freckles and Girl of the Limberlost how birdsongs were mimicked on a violin. They were, of course, played by ear, but if those notes had been copied down onto a score of music as each note was identified, a continuous line joining them would match just such a chart as I am suggesting you should draw.

So be sure to keep a pencil and paper in your pocket, to draw a bird's song as well as to describe the details of its size and plumage. When making a chart of "birds seen," the added information about song will make it just that much more interesting, and valuable in the recognition of species in following years.

Again, when bird's have settled on their nesting territories you will notice that all meadowlarks, for instance, do not sing absolutely the same order of notes. Perhaps you could show, by a chart such as this, how the two songs sung by individuals of the same species are different. Then in the fall, compare the spring song graph with the one you draw of the autumn song. I think you will find that the fall song is shorter, and the uplifting notes at the end are apt to be missing.

But apart from trying to keep its song in your exact memory, do use a pencil and paper when watching a new bird. Write down everything you see about it ... whether it has a white line over its eye... or not; whether the breast is pale, streaked, or has a spot, or more than one of these. Notice, and write down, details about white on wings or tail. Often it is just one of these small details that is needed to make recognition certain, when you compare descriptions in a bird guide..

It is a good idea to study the bird books in advance, for then you have more of an idea what to look for in the strange migrant if you come upon one unexpectedly. It is not often that a bird will wait while you run home for the book, bring it back and leaf through the pages to compare picture with reality. But while you do watch the strange visitor, let us hope it gives you opportunity also to "draw its song."

Lynx seen swimming in the Lac La Ronge area. - While prospecting in the La Ronge area in July, 1955, Mr. Czartoryski of Regina saw a Lynx swimming from the mainland to an island about 300 yards off shore. The lynx was making good progress, but when circled several times by the boat seemed to resent the interference and returned to the mainland. Observers: Mr. Czartoryski, Christopher Czartoryski, Jim Shamback, John Bird.

SAY'S PHOEBE. In the next issue of the Blue Jay we will print a description and an account of the occurrence of the Say's Phoebe in Saskatchewan. If you are acquainted with this bird please send notes or records to the Blue Jay Editor, 2335 Athol St., Regina. Please help to make this article as complete and valuable as possible. Which bird would you like for the December issue? 